DEVELOPMENT OF MANAGEMENT

AND ENTREPRENEURSHIP METHODS

ON TRANSPORT, № 3 (76), 2021
РОЗВИТОК МЕТОДІВ

УПРАВЛІННЯ ТА ГОСПОДАРЮВАННЯ

НА ТРАНСПОРТІ, № 3 (76), 2021
УДК 656.078.11

JEL L 90

DOI 10.31375/2226-1915-2021-3-29-46

ОГЛЯД ІСТОРІї ТА МІЖНАРОДНОГО ДОСВІДУ РОЗВИТКУ ТРАНСПОРТНОЛОГІСТИЧНИХ ЦЕНТРІВ

\section{T.A. Ковтун}

Д.т.н., доцент, професор кафедри

«Управління логістичними системами та проектами» Т.М. Смокова

к.т.н., ст. викладач кафедри

«Управління логістичними системами та проектами»

Одеський наиіональний морський університет, Одеса, Україна

Д.К. Ковтун

магістр з логістичного менеджменту, логіст

Одеський національний морський університет, компанія «EwalsCargo», Варшава, Польщза

Анотація. У статті розглянуто історію та міжнародний досвід створення $i$ функиіонування об'єктів транспортно-логістичної інфраструктури - транспортно-логістичних иентрів в $\mathrm{C}_{6}$ ропі, США та Азіатських краӥнах, визначено особливості та напрямки подальшого розвитку.

Надано характеристику поняття «транспортно-логістичний центр», що враховує особивості його структури, управління та функціонування сформоване Свропейською асоиіацією транспортно-логістичних иентрів.

Відповідно до иілей функиіонування транспортно-логістичних иентрів визначено основні складові елементи від наявності чи відсутності яких залежить клас транспортно-логістичного иентру.

У статті представлена класифікачія транспортно-логістичних центрів за наступними ознаками: поєднанням магістральних видів транспорту; потужсністю вантажопереробки, площі, займаної території $i$ комплексності надаваних клієнтурі транспортно-логістичних сервісних послуг; маситабами і адміністративним рівнем території, що обслуговується; характером спеціалізачіі терміналів в складі транспортно-логістичного центру і ступеня інтеграції з підприсмствами промисловості, торгівлі та ін.

Не дивлячись на різноманіття видів транспортно-логістичних иентрів, показано основні загальні ознаки всіх транспортно-логістичних иентрів, як складної системи, щчо включає декілька підсистем, об'єднаних інтеграчійними зв'язками, завдяки яким вона здатна виконувати логістичні функиії.

Ключові слова: транспортно-логістичний центр, транспортний потенціал, транспортнологістична інфраструктура.

\section{(C) Ковтун T.А., Смокова T.М., \\ Ковтун Д.К., 2021}

УДК 656.078.11

JEL L 90

DOI 10.31375/2226-1915-2021-3-29-46

ОБЗОР ИСТОРИИ

И МЕЖДУНАРОДНОГО ОПЫТА РАЗВИТИЯ

ТРАНСПОРТНО-ЛОГИСТИЧЕСКИХ ЦЕНТРОВ

Т.А. Ковтун

д.т.н., доцент, профессор кафедры

«Управление логистическими системами и проектами»

Т.М. Смокова

к.т.н., ст. преподаватель кафедры

«Управление логистическими системами и проектами»

Одесский национальный морской университет Одеса, Україна

Д.К. Ковтун

магистр логистического менеджмента, логист

Одесский национальный морской университет, компания «EwalsCargo», Варшава, Польша

Аннотация. В статье рассмотрена история и международный опьт создания и функиионирования объектов транспортно-логистической инфраструктуры - транспортно-логистических центров в Европе, США и Азиатских странах, определень особенности и направления дальнейтего развития.

Охарактеризовано понятие «транспортнологистический центр», учитывающий особенности его структуры, управления и функционирования, которое сформировано Европейской ассочиацией транспортно-логистических центров.

В соответствии с иелями функционирования транспортно-логистических чентров, определены основные составляющие элементы от наличия или отсутствия которых зависит класс транспортно-логистического иентра.

В статье представлена классификация транспортно-логистических центров по следуюшим признакам: сочетанием магистральных видов транспорта; мочностью грузопереработки, площади, занимаемой территории и комплексности предоставляемых клиентуре транспортно-логистических сервисных услуг; масштабам и административным уровнем обслуживаемой территории; характером специализации терминалов в составе транспортно-логистического иентра и степени интеграчии с предприятиями промышленности, торговли и др.

Несмотря на многообразие видов транспортно-логистических иентров, показаны основные общие признаки всех транспортно-логистических центров, как сложной системы, включающей несколько подсистем, объединенных интеграциионными связями, благодаря которым она способна выполнять логистические функиии.

Ключевые слова: транспортно-логистический иентр, транспортный потенциал, транспортно-логистическая инфраструктура. 
UDC 656.078.11

JEL L 90

DOI 10.31375/2226-1915-2021-3-29-46

\title{
OVERVIEW OF THE HISTORY AND INTERNATIONAL EXPERIENCE IN THE DEVELOPMENT OF TRANSPORT AND LOGISTICS CENTERS
}

\author{
Tetiana Kovtun \\ Doctor of Technical Sciences, Associate Professor, \\ Professor of the Department «Logistics Systems and Project Management» \\ ORCID: https://orcid.org/0000-0002-5410-4783 \\ teta.kovtun@gmail.com \\ Tetiana Smokova \\ Ph.D., Art. Lecturer, Department of «Logistics Systems and Project Management» \\ ORCID: https://orcid.org/0000-0002-0688-5677 \\ smokova.tm@gmail.com \\ Odessa National Maritime University, Odessa, Ukraine \\ Dmitry Kovtun \\ Master of Logistics Management, Logistics \\ ORCID: https://orcid.org/0000-0003-3443-2250 \\ mail.dmitrij.kovtun@gmail.com \\ Odessa National Maritime University, Company «EwalsCargo», Warsaw, Poland
}

Abstract. This article examines the history and international experience of creating and functioning of transport and logistics infrastructure facilities - transport and logistics centers in Europe, the USA, and Asian countries, and identifies specific features and directions of further development.

The concept of «transport and logistics center» is characterized, which takes into account the peculiarities of its structure, management, and functioning formed by the European Association of Transport and Logistics Centers.

For the first time the ideology of creating a large logistics complex dates back to 1960, when in France (near Paris) at the initiative of the state in cooperation with local authorities and private companies were established two specialized logistics centers «Garonor» and «Sogaris».

In accordance with the objectives of the functioning of transport and logistics centers, the main components of the class of transport and logistics centers are determined by their presence or absence.

This article presents the classification of transport and logistics centers for the following features: integration of main modes of transport; capacity of vantage processing, space, occupied territory and the complexity of the transport and logistics services provided by the cluster; scale and administrative level of the area, which is served by the nature of specialization of terminals in the transport and logistics center and the degree of integration with enterprises and industries, trade, etc.

Regardless of the diversity of types of transport and logistics centers, shows the main general features of all transport and logistics centers, as a complex system, which includes several subsystems, integrated links, due to which it is able to perform logistical functions.

Since existing scientific research is not enough to improve the state of methodological support of the process of creating transport-logistic infrastructure relevance of conducting research into the creation of the methodological basis of support of the processes of creation and functio-ning of transport-logistic centers.

Keywords: transport and logistics center, transport potential, transport and logistics infrastructure. 
DEVELOPMENT OF MANAGEMENT

AND ENTREPRENEURSHIP METHODS ON TRANSPORT, № 3 (76), 2021
РОЗВИТОК МЕТОДІВ

УПРАВЛІННЯ ТА ГОСПОДАРЮВАННЯ

НА ТРАНСПОРТІ, № 3 (76), 2021
Постановка проблеми. Економічний розвиток нашої країни і іï інтеграція в світову економіку напряму пов'язані $з$ розвитком транспортнологістичної інфраструктури. Щоб забезпечити безперебійну роботу глобальних транспортних артерій транспортних коридорів, що проходять через територію України завдяки ii вдалому географічному розташуванню, країні необхідна мережа транспортно-логістичних комплексів, створення яких позитивно вплине на розвиток прилеглих територій, збільшуючи їх інвестиційну привабливість. Як слідство, збільшиться товарообіг, податкові платежі до державного та місцевих бюджетів за рахунок розвитку внутрішньої інфраструктури транспортно-логістичного центру, відбудеться поштовх для успішнішого розвитку промисловості в прилеглих регіонах, збільшиться зайнятість населення довколишніх районів і міст, що з часом приведе Україну до значного підвищення конкурентоспроможності вітчизняного транспорту на міжнародних ринках перевезень [1-3].

Транспорт $є$ однією 3 базових галузей економіки України, географічне розташування якої сприяє формуванню на іiі території транспортних коридорів і вузлів міжнародного значення, що в свою чергу, призводить до підвищення привабливості транспортної галузі для вітчизняних і зарубіжних інвесторів. У таких умовах транспортна система стає основою для ефективного розвитку народногосподарського комплексу країни [4].

У статті 1 «Транспорт у системі суспільного виробництва» Закону України «Про транспорт» визнача- ється: «Транспорт є однією 3 найважливіших галузей суспільного виробництва i покликаний задовольняти потреби населення та суспільного виробництва в перевезеннях» [5]. Тобто, транспортний комплекс виконує найважливішу соціально-інфраструктурну функцію щодо забезпечення інтеграції економічного простору.

Пріоритетним завданням для України $є$ реалізація ії транспортного потенціалу та створення транзитного транспортного мосту, що поєднуватиме країни Європи, Азії та Сходу. Інтеграція транспортних мереж i транспорту України в міжнародну транспортну систему необхідна для залучення додаткових обсягів перевезень та валютних надходжень, скорочення транспортних витрат, наближення до міжнародних стандартів перевезень пасажирів та вантажів, енергетичних та екологічних показників роботи транспорту і збільшення частки експортного потенціалу України на міжнародному ринку транспортних послуг шляхом значного підвищення конкурентоспроможності українських перевізників; підтримання оперативної готовності транспортної системи України до використання iï в інтересах підвищення обороноздатності держави [6].

Зміни економічного клімату та умов господарювання, що привели до посилення конкурентної боротьби на ринку логістичних послуг, потребують адаптації елементів транспортнологістичної інфраструктури до системи економічних відносин шляхом еволюції організаційних форм.

Огляд останніх досліджень та літератури. Міжнародний досвід та історія створення об'єктів транспорт- 
но-логістичної інфраструктури висвітлюються в багатьох роботах українських та зарубіжних науковців таких, як М.В. Кондратюк, В.В. Кутирєв, А.М. Пасічник, І.Г. Смирнов, А.В. Титов, М.О. Устенко, Я.І. Шрамко, В.А. Шумаєва, Б.А. Анікін, В.В. Дибська, Е.И. Зайцев, В.І. Сергеєв, А.Н. Стерлінгова, С.В. Калантєєв, Л.Б. Міротін, Є.В. Миснік, В.А. Гудков, В.В. Зирянов, Т.А. Прокоф'єва, I. Сибірко, В. Григор'єв, Н.Г. Плетньова, I. Fechner, C.D. Higgins, M.P. Pretorius, J.-P. Rodrigue та інших. У своєму розвитку транспортно-логістична інфраструктура пройшла певні етапи, від простих складських приміщень до сучасних складних інтегрованих об'єктів типу транспортно-логістичних комплексів, хабів.

У роботі [7] пропонується авторська концепція еволюції формування об'єктів транспортно-логістичної інфраструктури, яка умовно поділена на наступні періоди:

- 1960-1980 pp. - склад;

- 1980-1990 pp. - вантажний

термінал;

центр;

- 1990-2000 pp. - логістичний

- 32000 p. - мультимодаль-

ний логістичний центр.

Розвиток об'єктів транспортнологістичної інфраструктури носить закономірний еволюційний характер та здійснюється у напрямку структур, що мають вищій ступень інтеграції іiі елементів.

У роботі [262] історія виникнення об'єктів транспортно-логістичної інфраструктури умовно поділена на 3 етапи:
- 1960-1970 pp. - становлен-

ня;

- кінець 1970-початок 1990-х

pp. - розвиток;

- середина 1990 - теперішній

час - інтеграція.

Еволюцію логістичних центрів поділено на 4 фази [8]:

1) фізичний розподіл - фаза, пов'язана 3 переміщенням і зберіганням товарів;

2) внутрішньо інтегрована логістика - фаза, для якої характерний комплексний підхід до управління матеріальними потоками;

3) зовні інтегрована логістика фаза послуг з доданою вартістю і організації спільної роботи компаній (початок 1990-х рр.);

4) глобальне управління ланцюгами постачань - під час цієї фази послуги 3 доданою вартістю стали важливим елементом в ланцюгу постачань, а кількість логістичних центрів по всьому світі значно збільшилася.

Деякі автори вже в другій половині XX століття перелічують проблеми і тенденції, що викликали необхідність створення логістичних центрів в Західній Європі [9]:

- брак складських площ у великих промислових і торгових центpax;

- розвиток мультимодальних (інтермодальних) перевезень 3 використанням контейнерів;

- збільшення обсягів вантажних перевезень, що призводить до надмірної завантаженості автодоріг і проблемам екології;

- брак портових потужностей і необхідність будівництва додатко- 
DEVELOPMENT OF MANAGEMENT

AND ENTREPRENEURSHIP METHODS ON TRANSPORT, № 3 (76), 2021
РОЗВИТОК МЕТОДІВ

УПРАВЛІННЯ ТА ГОСПОДАРЮВАННЯ

НА ТРАНСПОРТІ, № 3 (76), 2021 вих вантажопереробних і складських потужностей.

Вирішення цих проблем вимагало великих інвестицій, тому вчені та практики займались пошуком альтернативних шляхів розвитку транспортних систем і інфраструктури. Результатом таких пошуків стала поява в 80-хроках XX століття логістичних центрів, що забезпечують надання компаніям комплексу послуг, наприклад, заходів розширеного спектру складських послуг та сервісу дистрибуції, оренди обладнання, IT-аутсорсингу тобто перетворилися в 3PL i 4PL провайдерів логістичних послуг, a еволюція логістичних центрів i $\dddot{11}$ етапи відрізняються ступенем інтеграції учасників логістичного ланцюга i визначаються логістичними процесами, реалізованими на тому чи іншому етапі, а також видами потоків.

Мета та завдання дослідження. Метою наукової статті $\epsilon$ розгляд історії та міжнародного досвіду створення і функціонування об'єктів транспортно-логістичної інфраструктури, визначення іï особливостей та напрямків подальшого розвитку. Для досягнення мети дослідження поставлені наступні завдання:

1. Розглянути міжнародний досвід створення та функціонування транспортно-логістичних центрів в Європі, США, Азіатських країнах.

2. Надати характеристику поняття «транспортно-логістичний центр», його складових елементів, функцій та класифікації.

Основний матеріал дослідження. Розвиток об'єктів транспортно-логістичної інфраструктури носить закономірний еволюційний характер та здійснюється у напрямку структур, що мають вищій ступень інтеграції ii елементів. Традиційні ієрархічні та бюрократичні форми логістичної організації, що орієнтуються на стабільну ситуацію на ринку логістичних послуг, на сучасному етапі розвитку економічних відносин не змозі успішно конкурувати з більш гнучкими адаптивними структурами. Логістична діяльність завжди була досить динамічною та схильною до ризиків, тому значення гнучкості та адаптивності організаційної форми для виживання об'єкту логістичної інфраструктури важко переоцінити.

При цьому необхідно враховувати той факт, що розвиток бізнесу відбувається на тлі явних макроекономічних тенденцій, загальна спрямованість яких пов'язана з укрупненням масштабів діяльності, екстраординарними змінами в техніці і технологіях, що призводять до забезпечення інтенсивного росту знань, віртуалізації економіки, високого ступеня мобільності факторів виробництва праці, капіталу, інформації, а також посиленням впливу наукової та інноваційної діяльності на виробничі процеси [10].

Розглядаючи світовий досвід створення і функціонування логістичних центрів, особливої уваги слід приділити особливостям функціонування та еволюції логістичних центрів в Свропі, США, Азіатських країнах.

На даний момент у країнах, що входять до Європейського Союзу, нараховується близько 240 транспортно-логістичних центрів, що займають площу близько 26 тис. га, отже, на один транспортно-логістичний центр припадає близько 108 га. При 
DEVELOPMENT OF MANAGEMENT

AND ENTREPRENEURSHIP METHODS ON TRANSPORT, № 3 (76), 2021
РОЗВИТОК МЕТОДІВ

УПРАВЛІННЯ ТА ГОСПОДАРЮВАННЯ

НА ТРАНСПОРТІ, № 3 (76), 2021 цьому майже половина транспортнологістичних центрів сконцентрована у чотирьох країнах: Німеччині, Іспанії, Франції та Італії [11].

Створення крупних логістичних центрів почалося у Європі приблизно в 80-х роках $\mathrm{XX}$ століття. Вперше ідеологія створення великого логістичного комплексу відноситься до 1960 року, коли у Франції (в районі Парижа) 3 ініціативи держави у співпраці 3 місцевими органами влади та приватними компаніями були створені два спеціалізовані логістичні центри «Garonor» та «Sogaris». Основна причина створення центрів полягала в бажанні органів влади підвищити умови організації ванта-жопотоків в Парижі, які сильно погіршилися після війни [12].

У Західній Європі існує ряд прикладів успішно діючих і таких, що розвиваються, проектів транспортнологістичних розподільних центрів [13]:

- найбільший логістичний проект в Середземноморському басейні Франції - CLESUD (Centre Logistiquedel'EuropeduSud) - Південно-Свропейський логістичний центр;

$$
\text { - термінальні комплекси }
$$

GARONOR (ГAPOHOP) i SOGARIS (COГАРІС) близько Парижа;

- логістичний центр у Вероні (Італія) - Quadrante Europa Freight Village $\epsilon$ центром інтегрованих логістичних послуг 3 терміналом для обслуговування мультимодальних перевезень;

- логістичний парк в передмісті Мілана (Італія) - CSG Logistic Park;

- мережа мультимодальних вантажних терміналів в великих i середніх містах Німеччини, названих Гутерверке-центри (скорочено ГВЦ GVZ);

- логістичний мультимодальний центр в Роттердамському порту (Нідерланди) - найбільшому в світі;

- EuropaPark - один 3 найбільших логістичних парків Польщі недалеко від Варшави;

- логістичний центр Aviapolis («Авіаполіс») поблизу Гельсінкі (Фінляндія); на території ЛЦ знаходиться міжнародний аеропорт Ванта.

Діяльність крупних логістичних центрів вносить значний вклад в економіку країн: в Голландії 40 \% доходів від транспортного комплексу, Франції 31 \%, Німеччині - 25 \% [14].

Слід відзначити значимість країн Східної Свропи у створенні транспортно-логістичної системи Євросоюзу. В [15] це пов'язують 3 розширенням Свропейського Союзу та виходом на ринок транснаціональних компаній. Країни східної Свропи займають проміжне положення між Західною Європою і Росією, багато компаній-виробників переносять свої виробничі потужності в Східну Свропу 3 метою розширення діяльності, логістичні провайдери теж повинні слідувати цим тенденціям і освоювати нові ринки. Логістичний ринок у Східній Свропі характеризується широкими регіональними відмінностями. У той час як Чехія, Словаччина, Словенія, Угорщина і Польща досягли непоганих успіхів, Румунія, Болгарія та Хорватія сильно відстають. Чим далі на схід, тим логістична інфраструктура слабша.

У Китаї логістичні центри являють собою вільну економічну зону, в якій частково проводяться науково- 
DEVELOPMENT OF MANAGEMENT

AND ENTREPRENEURSHIP METHODS ON TRANSPORT, № 3 (76), 2021
РОЗВИТОК МЕТОДІВ

УПРАВЛІННЯ ТА ГОСПОДАРЮВАННЯ

НА ТРАНСПОРТІ, № 3 (76), 2021 дослідницькі розробки. Зокрема, в китайській провінції Тайвань логістичний центр поділений на три зони. В індустріальній зоні розміщене виробництво текстильної, хімічної та іншої промисловості. В науковій індустріальній зоні проходить дослідження й розвиток, підтримка виробництва й навчання за високотехнологічними напрямками. А в спеціальній зоні проводяться такі операції над вантажами, як складування, транспортування та торгівля [16].

В Японії логістичний центр (логістичний хаб) так, як і в Китаї створений за принципом вільної економічної зони. Тут проходить складування, класифікація, контроль, тестування, переробка, збір, запаковування та виставка імпортних товарів [17].

У США транспортно-логістичні центри $є$ результатом дій ринкових умов. Роль держави переважно обмежується створенням різних податкових та економічних стимулів. На додачу значні приватні інвестиції в транспортно-логістичні центри сприятимуть використанню прогресивних технологій та ефективному менеджменту даних центрів [11].

У 1996 році Україна приєдналась до Європлатформи - асоціаціі, що була заснована в 1991 році та об'єднала на той час транспортнологістичні асоціації наступних країн: Італії, Іспанії, Португалії, Франції, Німеччини, Греції, Угорщини, Люксембургу, Данії. Основна мета діяльності «Європлатформи» полягає у впровадженні концепції створення транспортно-логістичних центрів на європейському рівні по всьому світу, а також в розвитку взаємовідносин у транспортно-логістичній сфері між різними регіонами та країнами [14].

У 2003 році в Україні була розроблена «Концепція програми формування мережі логістичних центрів в системі міжнародних транспортних коридорів» [18], в якій говориться про плани будівництва близько 50 логістичних центрів на території нашої країни. На даний час в Україні спостерігається дефіцит сучасних логістичних центрів. Основну причину такого висновку спеціалісти бачать в відсутності повного набору логістичних функцій, що виконуються цими інфраструктурними об'єктами [3].

Варто зазначити, що у світі не існує одностайності щодо трактування поняття «транспортно-логістичний центр», його функцій та класифікації. Так, згідно 3 дослідженням, проведеним Макмастерським університетом (Канада) на замовлення Міністерства транспорту Онтаріо [19], у світі виділяють більше 20 термінів, які за своєю суттю близькі та описують таке явище, як транспортнологістичний центр [11].

Широка різноманітність логістичних концепцій в зарубіжній літературі призвела до появи безлічі термінів, аналогічних поняттю «транспортно-логістичний центр», це:

- вантажні села (freight-villages) - в США, СС;

- логістичні центри (centre-delo-gistique), транспортні платформи (plates-formeslogistiques/multimodales) - Франції;

лї;

- інтерпорт (interporti) - в Іта-

- центр руху товару (gueterverkehrszentren (GVZ)) - у Німеччині; 
DEVELOPMENT OF MANAGEMENT

AND ENTREPRENEURSHIP METHODS ON TRANSPORT, № 3 (76), 2021
РОЗВИТОК МЕТОДІВ

УПРАВЛІННЯ ТА ГОСПОДАРЮВАННЯ

НА ТРАНСПОРТІ, № 3 (76), 2021
- логістичний парк (logisticspark), вантажна платформа (platformfreightterminal) - в деяких європейських і американських країнах;

- координаційні вантажні центри (centrointegrado de mercancias),

- транспортні центри (centro de transporte), логістична площа (plazalogistica) - в Іспанії;

- центр залізничного сполучення (railservicecentre (RSC)) - в Голандії;

- транспортний центр (transportcentre) - в Данії [15].

Найбільш всеохоплюючим $\epsilon$ трактування поняття «транспортнологістичний центр», що враховує особливості його структури, управління та функціонування, сформоване Європлатформою (Європейською асоціацією транспортно-логістичних центрів): транспортно-логістичний центр - це певна територія, на якій усі види діяльності, пов'язані з транспортуванням, логістикою та дистрибуцією товарів як для національного, так і міжнародного транзиту, здійснюються різними операторами. Ці оператори можуть бути власниками або орендарями будівель та об'єктів (складів, перевальних центрів, автостоянок тощо), що були побудовані на території центру. Крім того, відповідно до правил вільної конкуренції, транспортно-логістичний центр повинен надати доступ усім компаніям, що беруть участь у діяльності, згаданій вище, та бажають працювати на території центру. Також транспортно-логістичний центр повинен бути обладнаним об'єктами громадської інфраструктури для виконання зазначених вище операцій. За можливості на території центру мають на- даватися державні послуги для користувачів транспортно-логістичного центру. Із метою стимулювання інтермодальних перевезень транспортнологістичний центр повинен мати доступ до якнайбільшої кількості видів транспорту (автомобільного, залізничного, морського, річкового, повітряного та трубопровідного). Зрештою, вкрайважливо, щоб управління транспортно-логістичного центру здійснювалась 3 єдиного центру, до складу якого можуть входити представники як і держави, так і приватного сектору [20].

Транспортно-логістичний центр повинен відповідати європейським стандартам і показникам якості для того, щоб забезпечити базу для прийняття ефективних комерційних і стійких логістичних i транспортних piшень [15], крім того діяльність транспортно-логістичного центру повинна призвести до виникнення синергетичного ефекту та забезпечити ефективне комерційне співробітництво учасників.

Відповідно до [21] основними цілями функціонування транспортнологістичних центрів $€$ :

- забезпечення координації та взаємодії видів транспорту та інших учасників транспортно-логістичного процесу;

- забезпечення високої якості транспортно-логістичного сервісу;

- забезпечення збереження товарів і вантажів на шляху, безпеки транспортування, переробки та зберігання;

- інформаційно-аналітичний супровід по всьому шляху проходження товарів і вантажів; 
DEVELOPMENT OF MANAGEMENT

AND ENTREPRENEURSHIP METHODS ON TRANSPORT, № 3 (76), 2021
РОЗВИТОК МЕТОДІВ

УПРАВЛІННЯ ТА ГОСПОДАРЮВАННЯ

НА ТРАНСПОРТІ, № 3 (76), 2021
- забезпечення управління наскрізними товарно-матеріальними потоками;

- зниження загальних транспортно-логістичних витрат за рахунок впровадження передових технологій, заснованих на принципах логістики.

- забезпечення максимального синергетичного ефекту на основі логістичної координації і узгодження економічних інтересів учасників транспортно-логістичного центру i партнерів по бізнесу.

Для досягнення вищевказаних цілей функціонування транспортнологістичний центр повинен мати у своєму складі певні елементи (табл.1).

Відповідно від наявності чи відсутності зазначених елементів залежить клас транспортно-логістичного центру. Нині в усьому світі логістичні провайдери, оператори, ріелтерські компанії використовують класифікацію $\mathrm{ABCD}$, яка об’єднує в собі усі класифікаційні ознаки i найбільш точно характеризує рівень логістичного центру.

У [21] пропонується класифікація транспортно-логістичних центрів за наступними ознаками:

- за поєднанням магістральних видів транспорту (залізнично-автомобільні; повітряно-автомобільні; залізнично-автомобільно-морські; автомобільно-водні; залізнично-автомобільно-водно-повітряні і т.д.);

- за потужністю вантажопереробки на терміналах, що входять до складу транспортно-логістичного центру, площі, займаної території i комплексності надаваних клієнтурі транспортно-логістичних сервісних послуг (великі і середні);

- за масштабами і адміністративним рівнем території, що обслуговується (регіональні, територіальні, республіканські, національні, міжнародні);

- за характером спеціалізації терміналів в складі транспортно-логістичного центру і ступеня інтеграції $з$ підприємствами промисловості, торгівлі та ін., що обслуговуються (транспортно-логістичний центр зі спеціалізованими терміналами по зберіганню і переробці лісових і будівельних вантажів, що швидко псуються продуктів харчування, аптекарських товарів, нафтових вантажів, цементу та ін.; транспортнологістичний центр $з$ центром оптової торгівлі, транспортно-логістичний центр 3 навчальним центром, транспортно-логістичний центр 3 реабілітаційно-оздоровчим комплексом, транспортнологістичний центр в складі індустріально-логістичного парку та багато іншого).

Не дивлячись на різноманіття видів транспортно-логістичних центрів, основними загальними ознаками всіх центрів $є$ :

- наявність декількох видів транспорту, що обслуговуються транспортно-логістичним центром, при суміщенні технології вантажопереробки; 
DEVELOPMENT OF MANAGEMENT

AND ENTREPRENEURSHIP METHODS

ON TRANSPORT, № 3 (76), 2021
РОЗВИТОК МЕТОДІВ

УПРАВЛІННЯ ТА ГОСПОДАРЮВАННЯ

НА ТРАНСПОРТІ, № 3 (76), 2021

Таблиия 1

Складові елементи транспортно-логістичного иентру

\begin{tabular}{|c|c|}
\hline $\begin{array}{c}\text { Літературне } \\
\text { джерело }\end{array}$ & Складові елементи транспортно-логістичного центру \\
\hline $\begin{array}{l}\text { Прокоф’єва } \\
\text { T.А. [21] }\end{array}$ & $\begin{array}{l}\text { Сучасний муьтимодальний транспортно-логістичний центр повинен мати в сво- } \\
\text { єму складі термінали зі спеціалізованими складськими приміщеннями для збе- } \\
\text { рігання і переробки вантажів; приміщення для виконання митних функцій поса- } \\
\text { довими особами митної служби; банки; транспортно-експедиційні та логістичні } \\
\text { фірми; брокерські і страхові компанії; службу охорони і безпеки; адміністративні } \\
\text { приміщення і офіси клієнтів; торгові представництва і бізнес-центри; центр } \\
\text { компетенції для прийняття оптимальних логістичних рішень; центри технічного } \\
\text { обслуговування рухомого складу транспорту; майданчики для відстою рухомого } \\
\text { складу транспорту; кімнати відпочинку та готелі, заклади харчування; центри } \\
\text { дистрибуції і оптово-роздрібної торгівлі з мережею магазинів; консалтингово- } \\
\text { аналітичні та інформаційні центри; реабілітаційно-оздоровчі комплекси. }\end{array}$ \\
\hline $\begin{array}{l}\text { Струтинська } \\
\text { I.B. [22] }\end{array}$ & $\begin{array}{l}\text { Незалежні бізнес структури транспортно-логістичного центру: загальний } \\
\text { вантажний термінал, розподільчий центр, готель, контейнерний термінал, } \\
\text { комбінований термінал, технічне обладнання, сервісний центр, комп’ютерний і } \\
\text { комунікативний центр, науковий і навчальний комплекс, склад для зберігання } \\
\text { небезпечних вантажів, збирання і пакування; } \\
\text { Транспортні компанії: перевізники, експедитори, судоходні компанії, брокери, } \\
\text { залізничні оператори, судновласники, авіаперевізники, оператори терміналів; } \\
\text { Послуги додаткової вартості: митниця, порт, поштові послуги, ветеринарні } \\
\text { служби, відділення зважування і вимірювання, страховики, компанії, що надають } \\
\text { в оренду трейлери, заправні станції, ремонтні майстерні, банки та інші допоміжні } \\
\text { послуги. }\end{array}$ \\
\hline $\begin{array}{l}\text { Цогоев В.Г., } \\
\text { Дзакоев З.Л., } \\
\text { Дзакоева Н.З. } \\
\text { [23] }\end{array}$ & $\begin{array}{l}\text { Підрозділи комплексу діляться на постійні, що відображають специфіку комп- } \\
\text { лексу, і змінні, які мають другорядний характер. В цілому склад підрозділів } \\
\text { комплексу може включати: адміністративна будівля з відповідними } \\
\text { допоміжними приміщеннями, призначене для передачі в оренду різним фірмам; } \\
\text { складський термінал (2-3 складу класності А +, А, В +, В); відкриті майданчики } \\
\text { контейнерів міжнародних стандартів 1А і СС; майданчики розвантаження та } \\
\text { завантаження контейнеровозів; парк навантажувачів для перевезення } \\
\text { контейнерів; приміщення і майданчики для експедиторських і транспортних } \\
\text { компаній; виробничі приміщення для передачі в оренду підприємствам; } \\
\text { індустріальний парк або технопарк (бізнес-центр + виробництво); автосалон; } \\
\text { автосервіс; автозаправку; магазини і об'єкти громадського харчування; готель; } \\
\text { медичний пункт; пункт технічного обслуговування транспортних засобів; митні } \\
\text { структури; брокерські структури; структури зв'язку; компанії, що займаються } \\
\text { переробкою вантажів; підприємства, що здійснюють ремонт транспортних } \\
\text { засобів, вантажної техніки та іншого обладнання; служби охорони; службу } \\
\text { пожежної безпеки; обладнані зупинки громадського транспорту; філії компаній, } \\
\text { що здійснюють міжнародні перевезення і оформлення транспортних документів; } \\
\text { філії страхових компаній; рекламні, юридичні та консультаційні фірми; } \\
\text { автомобільний майданчик; парковка; приміщення для відпочинку водіїв. }\end{array}$ \\
\hline
\end{tabular}


Продовження табл. 1

\begin{tabular}{|c|c|}
\hline $\begin{array}{c}\text { Літературне } \\
\text { джерело }\end{array}$ & Складові елементи транспортно-логістичного центру \\
\hline $\begin{array}{l}\text { Курс } \\
{[24]}\end{array}$ & $\begin{array}{l}\text { Зона мульти-/інтермодального терміналу: залізничний вокзал, склади } \\
\text { тимчасового зберігання, мульти-/ інтермодальний термінал; } \\
\text { Промислово-логістична зона: промислові та виробничі будівлі, } \\
\text { технопарки, наукові містечка, навчальні центри тощо; } \\
\text { Адміністративна зона: бізнес-центри з офісами, центр митного } \\
\text { управління і контролю, служба безпеки і експлуатації, страхові компанії, } \\
\text { транспортно-експедиційні, оптові торгові компанії і логістичні про- } \\
\text { вайдери, інформаційні та консалтингові компанії; } \\
\text { Зона комерційних послуг: ресторан/кафе, кейтеринг, готель, } \\
\text { конференц-зал, супермаркет, банк, хімчистка, ясла-садок, пошта, } \\
\text { медицина та інші; } \\
\text { Зона послуг для транспорту: парковка, сервіси та ремонтні майстерні, } \\
\text { автозаправна станція. }\end{array}$ \\
\hline $\begin{array}{l}\text { Миснік Є.В. } \\
{[9]}\end{array}$ & $\begin{array}{l}\text { До складу мультимодального транспортно-логістичного центру входять: } \\
\text { контейнерний термінал, який є ключовою ланкою МТЛЦ, криті склади } \\
\text { для різних родів вантажу, склад СТЗ, автостоянки і адміністративну } \\
\text { будівлю з готелем, сервісний, інформаційний, консалтинговий центри; } \\
\text { інші організації (сервісні компанії, логістичні компанії і ін.) можуть } \\
\text { також розташовуватися на території мультимодального транспортно- } \\
\text { логістичного центру. }\end{array}$ \\
\hline
\end{tabular}

Джерело: [25]

Відповідно від наявності чи відсутності зазначених елементів залежить клас транспортно-логістичного центру. Нині в усьому світі логістичні провайдери, оператори, ріелтерські компанії використовують класифікацію $\mathrm{ABCD}$, яка об'єднує в собі усі класифікаційні ознаки i найбільш точно характеризує рівень логістичного центру.

У [21] пропонується класифікація транспортно-логістичних центрів за наступними ознаками:

- за поєднанням магістральних видів транспорту (залізнично-автомобільні; повітряно-автомобільні; залізнично-автомобільно-морські; автомо-більно-водні; залізнично-автомобільно-водно-повітряні і т.д.);
- за потужністю вантажопереробки на терміналах, що входять до складу транспортно-логістичного центру, площі, займаної території і комплексності надаваних клієнтурі транспортно-логістичних сервісних послуг (великі і середні);

- за масштабами і адміністративним рівнем території, що обслуговується (регіональні, територіальні, республіканські, національні, міжнародні);

- за характером спеціалізації терміналів в складі транспортнологістичного центру і ступеня інтеграції 3 підприємствами промисловості, торгівлі та ін., що обслуговуються (транспортно-логістичний центр зі спеціалізованими терміналами по 
DEVELOPMENT OF MANAGEMENT

AND ENTREPRENEURSHIP METHODS ON TRANSPORT, № 3 (76), 2021
РОЗВИТОК МЕТОДІВ

УПРАВЛІННЯ ТА ГОСПОДАРЮВАННЯ

НА ТРАНСПОРТІ, № 3 (76), 2021 зберіганню і переробці лісових і будівельних вантажів, продуктів харчування, що швидко псуються, аптекарських товарів, нафтових вантажів, цементу та ін.; транспортно-логістичний центр 3 центром оптової торгівлі, транспортно-логістичний центр 3 навчальним центром, транспортнологістичний центр 3 реабілітаційнооздоровчим комплексом, транспортно-логістичний центр в складі індустріально-логістичного парку та багато іншого).

Не дивлячись на різноманіття видів транспортно-логістичних центрів, основними загальними ознаками всіх центрів $€$ :

- наявність декількох видів транспорту, що обслуговуються транспортно-логістичним центром, при суміщенні технології вантажопереробки;

- розміщення на території (або в безпосередній близькості) транспортних вузлів на перетині магістральних шляхів сполучення;

- основними елементами транспортно-логістичного центру є багатофункціональні термінальні комплекси, що забезпечують вантажонакоплення, вантажопереробку, короткострокове і тривале зберігання, сервісне і комерційно-ділове обслуговування;

- функціонування в складі транспортно-логістичного центру транспортно-експедиційних компаній - провайдерів логістичних послуг, які здійснюють комплексне транспортно-експедиційне обслуговування клієнтури;

- наявність в складі транспортно-логістичного центру інформаційних компаній (інформаційно- аналітичних логістичних центрів), що забезпечують інформаційний супровід перевізного процесу, зберігання, вантажопереробки, сервісного і інших видів логістичного обслуговування;

- застосування новітніх логістичних технологій при плануванні, організації і управлінні товарноматеріальними, транспортними, сервісними та супутніми інформаційними і фінансовими потоками;

- спрямованість діяльності транспортно-логістичного центру на забезпечення максимального синергетичного ефекту на основі встановлення партнерських, взаємовигідних відносин між учасниками транспортно-логістичного процесу при максимальному задоволенні запитів клієнтури як обслуговування [24].

Висновки. Необхідність створення в України сучасних транспортно-логістичних центрів $\epsilon$ особливо гострою в останні роки і вимагає негайного вживання заходів щодо іiі задоволення. Але вирішення даного практичного завдання потребує наявності сучасного методичного забезпечення, використання якого, по-перше, базуватиметься на застосування сучасних методів таких напрямків управління та економіки, як проджектменеджмент, ризик-менеджмент, менеджмент якості, логістика, а подруге, дозволить врахувати специфічні особливості створюваних складних об'єктів.

Отже, транспортно-логістичні центи як об'єкти транспортно-логістичної інфраструктури виникли завдяки поширенню логістичної інтеграції і стали невід'ємною складовою транспортно-логістичних систем, що надають можливість реалізації логіс- 
тичної інтеграції. Транспортно-логістичний центр являє собою складну систему, яка включає декілька підсистем, об'єднаних інтеграційними зв'язками, завдяки яким вона здатна виконувати логістичні функції.

Існуючих наукових розробок недостатньо для кардинального покращення стану 3 методичним забезпеченням процесу створення транс- портно-логістичної інфраструктури. Крім того, дослідження, в яких вивчення питання здійснюється на перетині вищевказаних методологій, на даний час майже відсутні. Такий стан речей визначає актуальність проведення досліджень щодо створення методичної бази підтримки процесів створення та функціонування транспортно-логістичних центрів.

\section{СПИСОК ЛІТЕРАТУРИ}

1. Герами В.Д., Колик А.В. О создании опорной сети логистических иентров в России. Логистические инновации и сочиильно-экономические эффектыл. М.: МАКС Пресс. 2013.

2. Соляннік К.В. Транзитний потенціал Украӥни в сучасних умовах господарювання // Вісник економіки транспорту і промисловості. 2018.

№ 62. C. 30-32.

3. Комарницький І.М., Питуляк Н.С., Когут І.В. Механізми формування логістичних иентрів // Polytechnic National University Institutional Repository. URL: http://ena.lp.edu.ua C. 190-196.

4. Ковтун T.А. Система моделей підтримки процесу ініціалазації проекту надання транспортних послуг. автореф. дис. ... канд. техн. наук: 05.13.22. Одеський наи. морський ун-т. Одеса, 2008. 22 c.

5. Про транспорт: Закон Украӥни від 10.11.1994 № 232/94-ВР. Дата оновлення 25.04.2019. URL: https://zakon.rada.gov.ua/laws/show/232/94вр (дата звернення: 15.09.2021).

6. Про затвердження Концепиії створення та функціонування національної мережі міжнародних транспортних коридорів в Україні: Постанова Кабінету Міністрів України від 04.04.1997 p. № 821. Офіиійний вісник Украӥни. 1997. № 37. С. 46.

7. Боняр С.М., Корнійко Я.Р. Еволючія формування мультимодальних транспортно-логістичних иентрів // Інвестииії: практика та досвід. 2012. № 7.

8. Дмитриев А.В. Логистическая инфраструктура: учебное пособие. СПб.:Изд-во СПбГУЭФ. 2012. 65 c.

9. Мысник Е.В. Мультимодальные транспортно-логистические центры: учеб. пос. Иркутск: ИрГУПС, 2016. 88 с.

10. Евтодиева Т.Е. Развитие организационных форм логистики // Вестник Самарского экономического университета. 2013. № 1 (99). C. 25-28.

11. ЯроменкоЛ.Л. Міжнародний досвід розбудови транспортнологістичних иентрів як спосіб розвитку транспортно-логістичної 
інфраструктури // Причорноморські економічні студії. Світове господарство $i$ міжнародні економічні відносини. 2016. Bип. 8. C. 201-204.

12. Шарапов С.А. Основные предпосылки для реализации проекта «Создание межрегиональных мультимодальных логистических иентров». URL: https://refdb.ru/look/1532603.html

13. Прокофьева Т.А., Сергеев В.И. Логистические иентры в транспортной системе России: учебн. пос. М.: Экономическая газета. 2012. $524 c$.

14. Боняр С.М., Корнійко Я.Р. Міжнародний досвід створення мультимодальних транспортно-логістичних центрів // Економіка та держава. Серія Економічна наука. № 3. 2012. С. 32-35.

15. Власов А.В. Появление, формирование и функционирование транспортно-логистических комплексов // Научный альманах. Экономические науки. 2016. № 4-1 (18). С. 55-59.

16. Романенко К.М. Створення логістичних центрів: іноземний досвід та перспективи України // Економіко-правовий розвиток сучасної Украӥни: матер. III Всеукр. наук. конф. студ., аспір. та молодих вчених (22-23 листопада 2013 р., м. Одеса) / за ред. д.е.н., проф. О.М. Кібік, д.ю.н., проф. О.П. Подиерковного; Національн. ун-т «Одеська юридична академія». Одеса: Фенікс, 2013. С. 214-217.

17. Ширяєва Л.В., Козеренко І.А. Перспективи розвитку логістичних иентрів в Україні на основі Свропейської та Азіатської моделей // Вісник Східноукраӥнського національного університету ім. Володимира Даля. № 4 (146). 2011. С. 74-81.

18. Концеепиія програми формування мережі логістичних центрів в системі міжнародних транспортних коридорів / Ю.М. Цвєтков, O.П. Kутах, М.В. Макаренко та ін. К., 2003.

19. MITL. (2011). An Exploration of the Freight Village Conceptandits Applicability to Ontario. Hamilton, ON: McMaster Institute for Transportation \& Logistics.

20. FV-2000. (1999). Quality of Freight Villages Structure and Operations. European Commission.

21. Прокофьева Т.А. Проектирование и организащия региональных транспортно-логистических систем. М.: Изд-во РАГС при Президенте РФ. 2009. 412 c.

22. Струтинська І.В. Становлення та розвиток логістичних цееттрів як чинник економічної стабілізації підприємств автомобілебудівної галузі. Автореферат дисертації на здобуття наукового ступеня кандидата економічних наук: 08.00.04 - економіка та управління підприємствами (за видами економічної діяльності). Тернопіль, 2012. 26 с.

23. Цогоев В.Г., Дзакоев З.Л., Дзакоева Н.З. Межрегиональный мультимодальный логистический комплекс: к вопросу о составе и структуре // 
Известия Московского государственного технического университета МАМИ. Экономика и экономические науки. 2014. № 1 (19). Т. 5. С. 5254.

24. Курова А.Ю. Организационно-методическое обеспечение процессов формирования и функционирования логистических иентров: дис. ... канд. экон. наук: 08.00.05. М.: ФГБОУ ВПО «Государственный университет управления», 2015. $139 \mathrm{c}$.

25. Смокова T.М. Ризико-орієнтоване управління інтеграчією в проєктах транспортно-логістичної інфраструктури: дис. канд. техн. наук: 05.13.22 - Управління проєктами та програмами. Одеса, 2021. 184 с.

\section{REFERENCES}

1. Gerami, V.D. \& Kolik, A.V. (2013). O sozdanii opornoy seti logisticheskih tsentrov $v$ Rossii [On the creation of a support network of logistics centers in Russia]. Logistics innovations and socio-economic effects. M. MAX Press. [in Russian].

2. Solyannik, K.V. (2018). Tranzytnyi potentsial Ukrainy v suchasnykh umovakh hospodariuvannia [Transit potential of Ukraine in modern economic conditions]. Visnyk ekonomiky transportu i promyslovosti - Bulletin of Transport Economics and Industry. № 62, 30-32. [in Ukraine].

3. Komarnytsky, I.M., Pytulyak, N.S. \& Kohut, I.V. (2018). Mekhanizmy formuvannia lohistychnykh tsentriv [Mechanisms of formation of logistics centers]. Polytechnic National University Institutional Repository. Retrieved from: http://ena.lp.edu.ua. 190-196. [in Ukraine].

4. Kovtun, T.A. (2008). Systema modelei pidtrymky protsesu initsialazatsii proektu nadannia transportnykh posluh [System of models to support the process of initialization of the project of providing transport services]. author's ref. dis. ... cand. tech. Science: 05.13.22. Odessa national Maritime University, Odessa, 22. [in Ukraine].

5. On transport: Law of Ukraine of 10.11.1994 № 232/94-VR. Date of update 04/25/2019. Retrieved from: https://zakon.rada.gov.ua/laws/show/232/94-вp (access date: 15.09.2021).

6. Pro zatverdzhennia Kontseptsii stvorennia ta funktsionuvannia natsionalnoi merezhi mizhnarodnykh transportnykh korydoriv $v$ Ukraini [On approval of the Concept of creation and functioning of the national network of international transport corridors in Ukraine]: Resolution of the Cabinet of Ministers of Ukraine of 04.04.1997 № 821. Official Gazette of Ukraine. № 37, 46. [in Ukraine].

7. Bonyar, S.M., \& Korniyko, J.R. (2012). Evoliutsiia formuvannia multymodalnykh transportno-lohistychnykh tsentriv [Evolution of formation of multimodal 
transport and logistics centers]. Investytsii: praktyka ta dosvid - Investments: practice and experience. №7. [in Ukraine].

8. Dmitriev, A.V. (2012). Logisticheskaya infrastruktura [Logistics infrastructure]: a textbook. SPb: izd-vo SPbGUEF, 65. [in Russian].

9. Mysnik, E.V. (2016). Multimodalnyie transportno-logisticheskie tsentryi [Multimodal transport and logistics centers: textbook pos]. Irkutsk: IrGUPS, 88. [in Russian].

10. Evtodieva, T.E. (2013). Razvitie organizatsionnyih form logistiki [Development of organizational forms of logistics]. Vestnik Samarskogo ekonomicheskogo universiteta - Bulletin of Samara University of Economics. №1 (99), 25-28. [in Russian].

11. Yaroshenko, L.L. (2016). Mizhnarodnyi dosvid rozbudovy transportnolohistychnykh tsentriv yak sposib rozvytku transportno-lohistychnoi infrastruktury [International experience in the development of transport and logistics centers as a way to develop transport and logistics infrastructure]. Prychornomorski ekonomichni studii. Svitove hospodarstvo i mizhnarodni ekonomichni vidnosyny - Black Sea Economic Studies. World economy and international economic relations. Vip. 8, 201-204. [in Ukraine].

12. Sharapov, S.A. (2017). Osnovnyie predposyilki dlya realizatsii proekta "Cozdanie mezhregionalnyih multimodalnyih logisticheskih tsentrov». The main prerequisites for the implementation of the project «Creation of interregional multimodal logistics centers». URL: https://refdb.ru/look/1532603.html [in Russian].

13. Prokofieva, T.A., \& Sergeev, V.I. (2012). Logistics centers in the transport system of Russia: textbook. pos. M.: Economic newspaper, 524. [in Russian].

14. Bonyar, S.M., \& Korniyko, J.R. (2012). Mizhnarodnyi dosvid stvorennia multymodalnykh transportno-lohistychnykh tsentriv [International experience in creating multimodal transport and logistics centers]. Ekonomika ta derzhava. Seriia Ekonomichna nauka - Economy and state. Series Economic Science № 3, 32-35. [in Ukraine].

15. Vlasov, A.V. (2016). Poyavlenie, formirovanie i funktsionirovanie transportnologisticheskih kompleksov [The emergence, formation and operation of transport and logistics complexes]. Nauchnyj al'manah. Ekonomicheskie naukiScientific almanac. Economic sciences. №4-1 (18), 55-59. [in Russian].

16. Romanenko, K.M. (2013). Stvorennia lohistychnykh tsentriv: inozemnyi dosvid ta perspektyvy Ukrainy [Creation of logistics centers: foreign experience and prospects of Ukraine]. Economic and legal development of modern Ukraine: mater. III All-Ukrainian. Science. conf. stud., aspir. and young scientists (November 22-23, 2013, Odessa) / ed. Doctor of Economics, Prof. OM Kibik, Doctor of Law, Prof. OP Podtserkovny; National University «Odessa Law Academy», Odessa: Phoenix, 214-217. [in Ukraine].

17. Shiryaeva, L.V. \& Kozerenko, I.A. (2011). Perspektyvy rozvytku lohistychnykh tsentriv v Ukraini na osnovi Yevropeiskoi ta Aziatskoi modelei [Prospects for the development of logistics centers in Ukraine on the basis of European and 
Asian models]. Visnyk Skhidnoukrainskoho natsionalnoho universytetu im. Volodymyra Dalia - Bulletin of the East Ukrainian National University. Vladimir Dahl. № 4 (146), 74-81. [in Ukraine].

18. Tsvetkov, Yu.M., Kutah, O.P., Makarenko, M.V., \& et al. (2003). Kontseptsiia prohramy formuvannia merezhi lohistychnykh tsentriv $v$ systemi mizhnarodnykh transportnykh korydoriv [The concept of the program of forming a network of logistics centers in the system of international transport corridors]. K. [in Ukraine].

19. MITL. (2011). An Exploration of the Freight Village Conceptandits Applicability to Ontario. Hamilton, ON: McMaster Institute for Transportation \& Logistics.

20. FV-2000. (1999). Quality of Freight Villages Structure and Operations. European Commission. [in Europe].

21. Prokofieva, T.A. (2009). Proektirovanie $i$ organizatsiya regionalnyih transportno-logisticheskih sistem [Design and organization of regional transport and logistics systems]. M.: RAGS Publishing House under the President of the Russian Federation, 412. [in Russian].

22. Strutynska, I.V. (2012). Stanovlennia ta rozvytok lohistychnykh tsentriv yak chynnyk ekonomichnoi stabilizatsii pidpryiemstv avtomobilebudivnoi haluzi [Formation and development of logistics centers as a factor of economic stabilization of enterprises in the automotive industry]. Abstract of the dissertation for the degree of candidate of economic sciences: 08.00 .04 economics and management of enterprises (by types of economic activity). Ternopil, 2012. 26 p. Retrieved from: http://elartu.tntu. edu.ua/ handle/ 123456789 /1851 (2011). [in Ukraine].

23. Tsogoev, V.G., Dzakoev, Z.L., \& Dzakoeva, N. Z. (2014). Mezhregionalnyiy multimodalnyiy logisticheskiy kompleks: $k$ voprosu o sostave i strukture [Interregional multimodal logistics complex: on the question of composition and structure]. Izvestiya Moskovskogo gosudarstvennogo tekhnicheskogo universiteta MAMI. Ekonomika i ekonomicheskie nauki-Proceedings of the Moscow State Technical University MAMI. Economics and economic sciences. № 1 (19), T. 5. 52-54. [in Russian].

24. Kurova, A.Yu. (2015). Organizatsionno-metodicheskoe obespechenie protsessov formirovaniya i funktsionirovaniya logisticheskih tsentrov [Organizational and methodical support of processes of formation and functioning of logistic centers]: dis. ... cand. econ. Science: 08.00.05. M.: FGBOU VPO «State University of Management», 139. [in Russian].

25. Smokova, T.M. (2021). Ryzyko-oriientovane upravlinnia intehratsiieiu v proiektakh transportno-lohistychnoi infrastruktury [Risk-oriented management of integration in projects of transport and logistics infrastructure]: dis. Cand. 
tech. Sciences: 05.13.22 - Management of projects and programs. Odessa, 184. [in Ukraine].

Стаття надійшла до редакиії 01.10.2021

Посилання на статтю: Ковтун Т.А., Смокова Т. М., Ковтун Д. К. Огляд історії та міжнародного досвіду розвитку транспортно-логістичних центрів // Розвиток методів управління та господарювання на транспорті: Зб. наук. праць, 2021. № 3 (76). С. 29-46. DOI 10.31375/2226-1915-2021-3-29-46.

Article received 01.10.2021

Reference a JournalArtic: Kovtun Tetiana, Smokova Tetiana \& Kovtun Dmitry. (2021). Overview of the history and international experience in the development of transport and logistics centers. Development of management and entrepreneurship methods on transport. 3 (76), 29-46. DOI 10.31375/2226-1915-2020-3-29-46. 